\title{
FAKTOR YANG BERHUBUNGAN DENGAN TUBERCULIN SKIN TEST POSITIF PADA PETUGAS KESEHATAN DI RUMAH SAKIT DI KOTA JEMBER
}

\section{Factors Related to Tuberculin Skin Test Positive In Healthcare Workers At Hospitals In Jember City}

\section{Hamidah Retno Wardani ${ }^{1}$, Ni Made Mertaniasih ${ }^{2}$, Soedarsono $^{2}$}

1. Prodi Ilmu Kedokteran Tropis, Fakultas Kedokteran, Universitas Airlangga

2. Fakultas Kedokteran, Universitas Airlangga

\section{Riwayat artikel}

Diajukan:

24 September 2020

Diterima:

25 September 2020

\section{Penulis Korespondensi:}

- Hamidah Retno

Wardani

- Prodi Ilmu Kedokteran

Tropis, Fakultas

Kedokteran, Universitas

Airlangga

hamidah.retno.wardani-

2018@fk.unair.ac.id

\section{Kata Kunci:}

Tuberculin skin test; healthcare workers; risk factor

\section{Abstrak}

Pendahuluan : Tuberkulosis merupakan penyakit infeksi yang tidak hanya ada di komunitas tetapi juga di tempat kerja seperti pelayanan kesehatan. Petugas kesehatan di Rumah Sakit memiliki risiko tinggi terpajan droplet yang mengandung Mycobacterium tuberculosis. Tujuan: Penelitian ini bertujuan untuk mendeteksi positif tuberculin skin test pada petugas kesehatan di Rumah Sakit di Kota Jember. Metode: penelitian ini merupakan penelitian kuantitatif dengan pendekatan cross sectional design. Penelitian ini menggunakan cross-sectional, pada bulan Januari sampai Maret 2020 di dua rumah sakit di kota jember. Masing-masing petugas kesehatan di unit perawatan TB dan unit perawatan non TB dievaluasi menggunakan Tuberculin skin test dengan cut-off $\geq 10 \mathrm{~mm}$ untuk positif tuberculin skin test. Hasil: Deteksi positif tuberculin skin test terjadi pada $77(60.2 \%)$ petugas kesehatan dari total 128 petugas kesehatan. Faktor risiko jenis kelamin laki-laki ( $p$-value $=0.329 ; \quad \mathrm{OR}=1.425 ; \mathrm{CI}=0.6499-2.904)$, rentang usia ( $\mathrm{p}$ value $=0.676 ; \mathrm{OR}=0.740 ; \mathrm{CI}=0.176-3.101), \mathrm{BMI}(p$-value $=0.539)$, riwayat merokok $(p-$ value $=0.132 ; \mathrm{OR}=2.059 ; \mathrm{CI}=0.796-5.330)$, riwayat kontak $\mathrm{TB}$ di keluarga ( $p$ value $=0.481 ; \mathrm{OR}=1.555 ; \mathrm{CI}=0.452-5.348$ ), riwayat bekerja di unit $\mathrm{TB}$ ( $p$-value $=0.692$; $\mathrm{OR}=1.154 ; \quad \mathrm{CI}=0.568-2.344)$ tidak memiliki hubungan bermakna dengan reaksi tuberculin skin test positif. Kesimpulan: Reaksi tuberculin skin test positif dengan prevalensi yang tinggi terjadi pada petugas kesehatan yang berisiko meningkatkan risiko terjadinya TB aktif pada petugas kesehatan di Rumah Sakit di Jember. Dibutuhkan suatu program untuk mencegah terjadinya TB pada petugas kesehatan.

\section{Abstract}

Background: Tuberculosis is an infectious disease that does not only exist in the community but also the workplace such as health services. Healthcare workers at the hospitals have a high risk of exposure to droplets containing Mycobacterium tuberculosis. Objective: This study aims to detect a positive tuberculin skin test on healthcare workers at the hospital in Jember City. Method: This study used a crosssectional study, from January to March 2020 in two hospitals in the city of Jember. Each of the healthcare workers in the TB care unit and the non-TB care unit were evaluated using the tuberculin skin test with a cut off $\geq 10 \mathrm{~mm}$ for a positive tuberculin skin test. Results: Detection of tuberculin skin test positive occurred in 77 (60.2\%) healthcare workers out of a total of 128 healthcare workers. Male gender risk factors ( $p$ value = $0.329 ; O R=1.425 ; C I=0.6499-2.904)$ age range $(p$-value $=0.676 ; O R=0.740 ; C I=$ 0.176-3.101), body mass index ( $p$-value $=0.539)$, smoking history $(p$-value $=0.132 ;$ OR $=2.059 ; C I=0.796-5.330)$, history of TB contacts in the family ( $p$-value $=0.481 ; O R=$ 1.555; $C I=0.452-5.348$ ), history of working in TB units ( $p$-value $=0.692 ; O R=1.154$; $C I=0.568-2.344)$ did not have a significant relationship with positive tuberculin skin test. Conclusion: A positive tuberculin skin test reaction with a high prevalence occurs in healthcare workers who are at risk of increasing the risk of developing active TB among healthcare workers at the Hospital in Jember. A program is needed to prevent TB in healthcare workers. 


\section{PENDAHULUAN}

Tuberkulosis merupakan penyakit infeksi yang tetap menjadi masalah di dunia (Lacerda et al., 2014). Perubahan populasi, status kesehatan yang tidak sesuai imunodefisiensi, ketidakmampuan dalam mengontrol penyakit, epidemik HIV/AIDS, pendapatan yang tidak seimbang, kelaparan, dan masalah psikologi di Asia dan Afrika khususnya, menyebabkan TB menjadi sesuatu yang harus di pertimbangkan (Iroezindu et al., 2016; Tudor et al., 2016). Tuberkulosis merupakan penyakit infeksi yang tidak hanya terjadi di komunitas atau populasi umum. Tetapi juga terjadi pada lingkungan pekerjaan. Salah satu kelompok yang berisiko tinggi terinfeksi TB adalah petugas kesehatan.

Sebuah penelitian dengan
membandingkan populasi umum dengan petugas kesehatan, risiko TB dilaporkan lebih tinggi tiga kali lipat di Estonia, enam kali lipat di Serbia, dan 4.8 kali lipat lebih tinggi di Peru (Salehi \& Metanat, 2016). Penelitian lain yang dilakukan oleh Zhou et al tahun 2014 di China melaporkan bahwa $58 \%$ petugas kesehatan didapatkan hasil positif pada pemeriksaan TST (Zhou et al., 2014). Skrining infeksi TB dapat diidentifikasi menggunakan tuberculin skin test (TST) atau uji interferon-gamma release assay (IGRA). Penggunaan tuberculin skin test (TST) masih direkomendasikan karena IGRA dapat meningkatkan biaya jika digunakan untuk menggantikan TST di negara dengan penghasilan rendah dan menengah, penggunaan TST juga direkomendasikan di negara dengan beban TB yang tinggi. CDC and the Occupational Safety and Health Administration (OSHA) menyatakan bahwa salah satu program kontrol yang sesuai untuk melakukan skrining dan pemeriksaan petugas kesehatan yang terinfeksi $M$. tuberculosis adalah menggunakan TST (CDC, 2014; Savero et al., 2011). Studi ini bertujuan untuk menentukan prevalensi hasil tuberculin skin test positif dan menentukan faktor risiko yang berhubungan dengan hasil reaksi tuberculin skin test positif pada petugas kesehatan di Rumah Sakit di Kota Jember. Hipotesis yang didapatkan dalam penelitian ini adalah terdapat hubungan faktor risiko jenis kelamin, usia, BMI, merokok, kontak TB di keluarga dan riwayat di unit TB dengan hasil reaksi tuberculin skin test positif pada petugas kesehatan di rumah sakit di Kota Jember.

\section{METODE}

Studi cross-sectional dilaksanakan di dua rumah sakit di Kota Jember pada bulan Januari-Maret
2020. Sampel berasal dari petugas kesehatan yang berada di unit perawatan TB dan unit perawatan non $\mathrm{TB}$, tidak memiliki riwayat $\mathrm{TB}$ dan pengobatan TB. Tidak memiliki riwayat reaksi TST sebelumnya $\geq 15 \mathrm{~mm}$, tidak mengidap penyakit komorbid dan imunokompromais (HIV, DM, CKD, kanker), tidak memiliki riwayat menerima imunisasi kurang dari 1 bulan yang lalu, mengkonsumsi obat-obatan penekan kekebalan tubuh atau kortikosteroid, tidak mengalami luka bakar luas atau eksim, riwayat menderita infeksi virus (hepatitis) dalam satu bulan terakhir, tidak dalam kondisi hamil dan tidak mengalami TB aktif.

Sampel dipilih dengan stratified random sampling. Total terdapat 128 responden. Masingmasing petugas kesehatan yang terpilih mengisi inform concent serta kuesioner terstandarisasi. Kuesioner memuat pertanyaan tentang identitas diri yang di inisialkan dan informasi demografi, riwayat kesehatan responden dan keluarga, riwayat penyakit $\mathrm{TB}$, serta riwayat bekerja di unit TB.

Single-step TST menggunakan 10 international units (IU;0,1 ml) tuberkulin (purified protein derivative) PPD RT-23. TST dilakukan dengan metode mantoux oleh petugas yang berpengalaman dengan menginjeksikan tuberculin pada intrakutan dengan jarak 2-3 inch dari lipatan siku di permukaan bagian atas. Responden kembali 48-72 jam setelah dilakukan TST untuk mendapatkan hasil, yang dikonfirmasi oleh dokter spesialis. Diameter horizontal dari lebar indurasi diukur menggunakan penggaris yang terstandarisasi dan hasil dibaca oleh dokter spesialis yang berpengalaman. Indurasi TST dengan cut-off point $\geq 10 \mathrm{~mm}$ untuk TST positif. Data dianalisis menggunakan Statistical Product and Service Solutions (SPSS) for windows versi 16.0. Setiap variabel akan ditampilkan dalam bentuk frekuensi dan persentase serta dianalisis menggunakan uji chi-square dengan hubungan yang signifikan jika $p$-value $<0,05$. Semua data yang didapat dari responden dikodekan dan dirahasiakan serta disimpan dengan baik.. Studi ini mendapatkan ijin etik oleh Ethics Review Board Rumah Sakit Paru Jember Provinsi Jawa Timur, 002/RSP/KEPK/2020.

\section{HASIL DAN PEMBAHASAN HASIL PENELITIAN}

Data didapatkan dari 128 responden dan keseluruhannya melengkapi interview. Seluruh responden menjalani pemeriksaan TST dengan cut-off $\geq 10 \mathrm{~mm}$ untuk hasil TST positif. Analisis 
univariat didapatkan bahwa jenis kelamin dengan hasil TST positif terbanyak adalah jenis kelamin laki-laki yaitu $40(51.9 \%)$ dengan rentang usia 20-49 tahun sebanyak 71 (92.2\%). Dalam penelitian ini juga melaporkan bahwa responden dengan BMI normal (18,5-25) memiliki hasil TST positif terbanyak yang berjumlah $53(68.8 \%)$ dan dengan kebiasaan tidak merokok sebanyak $58(75.3 \%)$. Petugas kesehatan dengan riwayat tidak memiliki kontak TB di keluarga memiliki hasil TST positif terbanyak yaitu $68(88.3 \%)$ dan memiliki riwayat bekerja di unit TB sebanyak 42 $(54.5 \%)$. Karakteristik responden dan analisis faktor yang berhubungan dengan TST positif disajikan pada tabel 1 .

Hasil uji chi-square menunjukkan bahwa faktor jenis kelamin, usia, BMI, merokok, kontak TB di keluarga dan riwayat bekerja di unit TB tidak memiliki hubungan yang bermakna dengan hasil tuberculin skin test positif pada petugas kesehatan di rumah sakit. Berdasarkan tabel 2 menggambarkan bahwa jumlah indurasi TST positif $\geq 10 \mathrm{~mm}$ lebih banyak dibandingkan dengan indurasi TST $<10 \mathrm{~mm}$. Jumlah TST positif $\geq 10 \mathrm{~mm}$ berjumlah $50(38.5 \%), \geq 15 \mathrm{~mm}$ berjumlah $20(15.4 \%)$ dan $\geq 20 \mathrm{~mm}$ sebanyak 7 $(5.4 \%)$

\section{PEMBAHASAN}

Petugas kesehatan memiliki risiko tinggi terpajan tuberkulosis di tempat kerja. CDC and the Occupational Safety and Health Administration (OSHA) menyatakan bahwa salah satu program kontrol yang sesuai untuk melakukan skrining dan pemeriksaan petugas kesehatan yang terinfeksi $M$. tuberculosis adalah dengan menggunakan TST (Savero et al., 2011). Pemeriksaan menggunakan TST ini merupakan salah satu langkah untuk mendeteksi terjadinya infeksi TB pada petugas kesehatan guna menurunkan insiden tuberkulosis.

Tuberculin Skin Test (TST) digunakan untuk mengukur reaksi hipersensitifitas tipe lambat yang diikuti dengan reaksi inokulasi intradermal dengan antigen $M$. Tuberculosis (Tang \& Johnston, 2017). Tuberkulin adalah komponen protein kuman TB yang mempunyai sifat antigenik yang kuat, merupakan ukuran respon inflamasi pada kulit setelah penyuntikan secara intrakutan. Uji tuberkulin digunakan untuk mendeteksi adanya infeksi Mycobacterium tuberculosis atau telah ada kompleks primer dalam tubuh dan telah terbentuk imunitas seluler terhadap TB. Hasil tuberkulin positif jika indurasi yang dihasilkan $\geq 10 \mathrm{~mm}$ terutama pada kelompok berisiko seperti petugas kesehatan (CDC, 2019).

Berdasarkan penelitian ini terdapat 77 petugas kesehatan memiliki hasil tuberculin skin test $\geq 10$ $\mathrm{mm}$. Prevalensi positif TST pada petugas kesehatan saat ini lebih tinggi dibandingkan dengan laporan penelitian sebelumnya. Prevalensi TST positif dihubungkan pada prevalensi TB di populasi umum (Salehi \& Metanat, 2016). Data yang didapatkan pada penelitian ini jenis kelamin laki-laki memiliki frekuensi lebih banyak dibandingkan dengan jenis kelamin perempuan. Berdasarkan hasil statistic chi-square didapatkan tidak ada hubungan yang bermakna antara jenis kelamin responden dengan TST positif. Berbeda dengan penelitian yang dilakukan oleh Severo et al, tahun 2011 yang melaporkan bahwa TST positif lebih banyak terjadi pada jenis kelamin perempuan $(45.8 \%)$. Jenis kelamin laki-laki diketahui sebagai faktor risiko infeksi TB karena dampak dari sosio kultural. Hal ini sejalan dengan penelitian sebelumnya yang menjelaskan bahwa jenis kelamin juga mempengaruhi jumlah kejadian TB laten pada petugas kesehatan dengan pemeriksaan TST positif.

Penelitian ini juga melaporkan bahwa rentang usia dengan hasil TST positif terbanyak terjadi pada usia 20-49 tahun. Berdasarkan hasil statistic chi-square didapatkan tidak ada hubungan yang bermakna antara usia responden dengan TST positif. Menurut WHO tahun 2014 menyatakan bahwa insiden TB tertinggi secara global terjadi pada usia 45-55 tahun (usia produktif) dan wilayah Pasifik Barat, Mediterania Timur dan Asia Tenggara memiliki insiden yang tinggi pada lansia yang puncaknya terjadi pada usia $\geq 65$ tahun (WHO, 2014). Karena saat lansia sistem imunitas akan melalui berbagai macam perubahan dan mengalami penurunan (Simon, Hollander \&McMichael, 2015). Salah satu indicator dari perubahan system imunitas adalah perubahan karakteristik pada sel $\mathrm{T}$ yang berperan penting untuk bertahan dan melawan mikroorganisme seperti virus dan bakteri (Deng et al., 2019). Kondisi ini dapat meberikan dampak peningkatan kerentanan terhadap infeksi khususnya infeksi TB (Erawati \& Andriany, 2020).

Penelitian ini juga melaporkan responden dengan BMI normal (18,5-25) memiliki hasil TST positif terbanyak dan berdasarkan hasil statistic chi-square didapatkan tidak ada hubungan yang bermakna antara BMI responden dengan TST positif. 
Tabel. 1. Data demografi dan faktor yang berhubungan dengan tuberculin skin test positif pada petugas kesehatan di rumah sakit.

\begin{tabular}{|c|c|c|c|c|c|c|}
\hline \multirow[t]{3}{*}{ Variabel } & \multicolumn{4}{|c|}{ Reaksi Tuberkulin } & \multirow{3}{*}{$\begin{array}{c}\text { Odd ratio } \\
\text { (Coefisien } \\
\text { interval) }\end{array}$} & \multirow[t]{3}{*}{$P$-Value } \\
\hline & \multicolumn{2}{|c|}{ TST Positif } & \multicolumn{2}{|c|}{ TST Negatif } & & \\
\hline & $\mathrm{N}$ & $\%$ & $\mathrm{~N}$ & $\%$ & & \\
\hline \multicolumn{7}{|l|}{ Jenis kelamin } \\
\hline - Laki-laki & 40 & 51.9 & 22 & 43.1 & \multirow{2}{*}{$\begin{array}{c}1.425(0.699- \\
2.904)\end{array}$} & \multirow[t]{2}{*}{0.329} \\
\hline - $\quad$ Perempuan & 37 & 48.1 & 29 & 56.9 & & \\
\hline \multicolumn{7}{|l|}{ Usia } \\
\hline - $\quad 20-49$ & 71 & 92.2 & 48 & 94.1 & \multirow{2}{*}{$\begin{array}{c}0.740(0.176- \\
3.101)\end{array}$} & \multirow[t]{2}{*}{0.676} \\
\hline$-\quad>50$ & 6 & 7.8 & 3 & 5.9 & & \\
\hline \multicolumn{6}{|l|}{ BMI } & \multirow{4}{*}{0.539} \\
\hline$-\quad<18.5$ & 4 & 5.2 & 1 & 2 & & \\
\hline - $\quad 18.5-25$ & 53 & 68.8 & 34 & 66.7 & & \\
\hline$-\quad>25$ & 20 & 26 & 16 & 31.4 & & \\
\hline \multicolumn{6}{|l|}{ Merokok } & \multirow{3}{*}{0.132} \\
\hline - Ya & 19 & 24.7 & 7 & 13.7 & $2.059(0.796-$ & \\
\hline - Tidak & 58 & 75.3 & 44 & 86.3 & $5.330)$ & \\
\hline \multirow{2}{*}{\multicolumn{7}{|c|}{$\begin{array}{l}\text { Kontak TB di } \\
\text { keluarga }\end{array}$}} \\
\hline & & & & & \multirow{3}{*}{$\begin{array}{l}1.555(0.452- \\
5.348)\end{array}$} & \multirow{3}{*}{0.481} \\
\hline$-\quad Y a$ & 9 & 11.7 & 4 & 7.8 & & \\
\hline - $\quad$ Tidak & 68 & 88.3 & 47 & 92.2 & & \\
\hline \multicolumn{7}{|c|}{$\begin{array}{l}\text { Riwayat di unit TB } \\
-\quad \text { Ya }\end{array}$} \\
\hline - $\quad$ Tidak & 42 & 54.5 & 26 & 51 & \multirow{2}{*}{$\begin{array}{c}1.154(0.568- \\
2.344)\end{array}$} & \multirow[t]{2}{*}{0.692} \\
\hline & 35 & 45.5 & 25 & 49 & & \\
\hline
\end{tabular}

Tabel 2.Frekuensi reaksi tuberculin skin test pada petugas kesehatan

\begin{tabular}{ccc}
\hline Reaksi tuberculin skin test & Jumlah $(\mathrm{N}=128)$ & Persentase $(\%)$ \\
\hline$<5 \mathrm{~mm}$ & 28 & 21.5 \\
$\geq 5 \mathrm{~mm}$ & 23 & 17.7 \\
$\geq 10 \mathrm{~mm}$ & 50 & 38.5 \\
$\geq 15 \mathrm{~mm}$ & 20 & 15.4 \\
$\geq 20 \mathrm{~mm}$ & 7 & 5.4 \\
\hline
\end{tabular}

Infeksi mycobacterium merupakan infeksi yang probabilistik dan bukan deterministik. Dipengaruhi oleh beberapa faktor walaupun BMI normal, namun faktor lain seperti imunitas, penyakit komorbid, lingkungan dan kontak juga akan berpengaruh. BMI pada pasien TB pun dapat berubah dari yang semula normal menjadi malnutrisi ataupun obesitas (Pratomo et al., 2012).

Frekuensi TST positif juga banyak terjadi pada petugas kesehatan dengan $\mathrm{BMI}>25 \mathrm{~kg} / \mathrm{m}$. Penelitian lain menjelaskan bahwa infeksi TB tidak hanya dipengaruhi oleh status malnutrisi. Obesitas juga memiliki dampak negatif terhadap infeksi TB. Penelitian ini melaporkan bahwa BMI $\geq 28 \mathrm{~kg} / \mathrm{m}$ berhubungan dengan dampak negatif penurunan fungsi imun dan pertahanan host pada individu yang mengalami obesitas. Akumulasi jaringan adiposa dapat melemahkan pertahanan paru host melalui kekacauan metabolisme. Ini merupakan mekanisme pokok hubungan obesitas dan infeksi TB yang dapat menyebabkan jaringan adiposa memberikan respon mediator imun yang berbeda (Zhang et al., 2017). Status gizi mempengaruhi fungsi sistem cell mediated immunity (CMI). Meskipun belum sepenuhnya dipahami, namun juga tidak diragukan faktor gizi juga mempengaruhi kapasitas sistem cell mediated immunity (CMI) untuk melawan basil TB (Cegielski \& McMurray, 2004). Studi crosssectional dengan jumlah sampel yang besar melaporkan bahwa kelebihan berat badan dapat meningkatkan terjadinya TB laten (Chen et al., 2015).

Hasil TST positif terbanyak juga terjadi pada responden yang tidak merokok dan berdasarkan uji statistic chi-square bahwa kebiasaan merokok tidak memiliki hubungan yang bermakna terhadap hasil tuberkulin positif pada petugas kesehatan. Hal ini berbeda dengan beberapa penelitian sebelumnya yang menyatakan bahwa paparan rokok dapat menghambat sel $\mathrm{T}$ paru untuk memproduksi IFNgamma selama dirangsang secara in vitro dengan 
anti-CD3 dan dapat meningkatkan kerentanan terhadap infeksi M. tuberculosis (Feng et al., 2011). Namun dalam penelitian ini hasil TST positif terbanyak pada responden yang tidak merokok. Hal ini dapat disebabkan oleh responden yang memiliki riwayat pernah terpajan oleh asap rokok. Karena pajanan rokok secara perlahan juga akan menurunkan persentase dendritik sel di paru dan merubah ekspresi molekul kostimulatornya. Rokok juga mencegah ekspansi spesifik dan aktivasi maksimal sel $\mathrm{T}$ CD4 dan menurunkan jumlah $\mathrm{CD}^{+}$yang telah diaktivasi dan sel $\mathrm{T} \mathrm{CD}^{+}$untuk merespon mikroorganisme. Akibatnya proses netralisasi mikroorrganisme akan menurun, dan proteksi tubuh untuk melawan virus dan bakteri patogen juga akan menurun (Robbins et al., 2004).

Variabel lain yang dianalisis dalam penelitian ini adalah kontak TB dengan keluarga Sebuah penelitian menemukan bahwa tinggal di tempat yang sama dengan pasien TB yang menular atau berbagi udara dari sistem ventilasi yang sama adalah penentu inti penularan TB (Migliori et al., 2019). Penelitian ini juga melaporkan bahwa petugas kesehatan dengan riwayat bekerja di unit TB memiliki frekuensi terbanyak dengan hasil TST positif. Berdasarkan hasil statistic chi-square didapatkan tidak ada hubungan yang bermakna antara riwayat di unit TB dengan hasil TST positif. Unit perawatan TB merupakan unit yang membutuhkan sistem ventilasi yang adekuat untuk mencegah tranmisi TB. Perhatian khusus diberikan pada area yang berisiko tinggi untuk metransmisikan droplet seperti bangsal TB, area prosedur tindakan, dan ruang isolasi TB (Allyn \& Brewer, 2018). Menurut penelitian yang dilakukan oleh Nonghanphithak et al, tahun 2016 menyatakan bahwa unit kerja di rumah sakit dapat mempengaruhi terhadap pajanan dan merupakan tempat yang berisiko tinggi untuk menyebabkan terjadinya infeksi TB pada petugas kesehatan seperti pada laboratorium pemeriksaan TB. Termasuk bekerja di unit yang langsung berhubungan dengan pasien TB dapat meningkatkan risiko paparan pada petugas kesehatan (Nonganpithak et al, 2016; Borroto et al., 2011; Powell et al., 2011; He et al., 2012; Zhang et al., 2013).

Penelitian yang dilakukan oleh Park tahun 2018 menunjukkan bahwa pengalaman terpajan pasien TB yang belum berobat lebih besar frekuensinya terjadi pada petugas kesehatan yang bekerja di unit perawatan TB dibandingkan dengan petugas kesehatan yang bekerja di unit perawatan non TB yaitu sebesar $78,8 \%$ dan $61,9 \%$. Mengingat bahwa pasien TB sangat infeksius sebelum melakukan pengobatan, maka petugas kesehatan yang bekerja di unit perawatan TB lebih berisiko terinfeksi TB dibandingkan dengan petugas kesehatan yang bekerja di unit perawatan non TB (Park, 2018).

Selain itu reaktifitas BCG juga berpengaruh terhadap hasil TST. Hal tersebut dipengaruhi beberapa faktor seperti usia ketika melakukan imunisasi BCG, interval waktu dari awal melakukan imunisasi BCG dengan diperiksanya TST, jumlah dosis dan efek booster merupakan efek infeksi alami yang dihubungkan antara reaktifitas TST dan BCG. Imunisasi BCG juga dapat berespon terhadap nontuberculous mycobacterium infection yang dapat menimbulkan hasil false positive. Penelitian ini menggunakan cut off $\geq 10 \mathrm{~mm}$ untuk meminimalisir hasil false-positive pada TST (Yoon et al., 2017). Penelitian lain melaporkan rentang waktu yang bervariasi dari 1-25 tahun, dengan rangsangan $\mathrm{BCG}$ yang menghasilkan reaktifitas positif TST pada saat dewasa dan respon TST $>10 \mathrm{~mm}$ pada dewasa tidak dapat dihubungkan secara nyata dengan imunisasi saat neonatus di negara dengan prevalensi yang rendah. Studi lain juga menjelaskan bahwa respon positif TST meningkat seiring dengan berjalannya waktu, dan atau tanpa imunisasi BCG sebelumnya. Sebuah studi yang meneliti tentang sensitivitas dan spesifitas TST pada petugas kesehatan di negara dengan beban TB yang tinggi merekomendasikan untuk menggunakan cut off $\geq$ $10 \mathrm{~mm}$. Cut off ini menunjukkan tingkat sensitifitas dan spesifitas TST sebesar 80\% dan $61 \%$. Tetapi ketika menggunakan level cut off yang berbeda maka akan mengubah sensitifitas dan spesifitas. Spesifitas biasanya digunakan sebagai referensi untuk melakukan skrining pada petugas kesehatan yang berisiko terinfeksi TB (CDC, 2014).

\section{KESIMPULAN}

Penelitian didapatkan frekuensi tuberculin skin test mencapai $60 \%$ dari total keseluruhan responden dan tidak ada hubungan yang bermakna dengan faktor risiko seperti jenis kelamin, usia, BMI, kebiasaan merokok, kontak TB keluarga serta riwayat di unit TB. Skrining pada petugas kesehatan merupakan langkah yang penting dan diperlukan dalam menekan kejadian infeksi tuberculosis pada petugas kesehatan. Tidak hanya faktor risiko yang berhubungan dengan pekerjaan, faktor risiko yang 
berhubungan dengan kondisi individu juga dapat menjadi faktor pencetus petugas kesehatan terinfeksi tuberkulosis .

\section{DAFTAR PUSTAKA}

Lacerda NB, Temoteo CA, Figueiredo MRM, Luna DT, Sousa AN, Abreu C, 2014. Individual and social vulnerabilities upon acquiring tuberculosis: A literature systematic review. Int Arch Med, 7:35.

Iroezindu MO, Ofondu EO, Mbata GC, van Wyk B, Hausler HP, Dh A, 2016. Factors associated with prevalent tuberculosis among patients receiving highly active antiretroviral therapy in a Nigerian tertiary hospital. Ann Med Health Sci Res, 6:120-8.

Tudor C, Van der Walt ML, Margot B, Dorman SE, Pan WK, Yenokyan G, et al. Occupational risk factors for tuberculosis among healthcare workers in KwazuluNatal, South Africa, 2016. Clin Infect Dis, 62(Suppl 3):S255-61.

Salehi M, Mood B S, Metanat, 2016. Positive tuberculin skin test among health care workers: prevalence and risk factors in teaching hospitals of a highly endemic region for tuberculosis, Zahedan, Iran. International Journal Infectious, doi:10.17795/iji-36158.

Zhou F, Zhang L, Gao L, Hao Y, Zhao X, Liu J, Lu J, Li X, Yang Y, Chen J, Deng Y, 2014. Latent tuberculosis infection and occupational protection among health care workers in two types of public hospital in China. PLoS ONE, doi:10.1371/journal.pone.0104673.

Centers of Disease Control and Prevention. Tests for TB infection: tuberculin skin test (TST) (Serial Online) 2014 (Cited 2019 August 1). Available from https://www.cdc.gov/tb/publications/ltbi/di agnosis.htm\#two Step TST Testing.

Severo KGP, Oliveira JdS, Carneiro M, Valim ARM, Krummenauer EC, Possuelo LG, 2011. Latent tuberculosis in nursing professional of a Brazilian hospital. Journal of Occupational Medicine and Toxicology, 6:15.

Tang P, Johnston J, 2017. Treatment of latent tuberculosis. Curr Treat Options Infect Dis, DOI 10.1007/s40506-017-0135-7.

CDC. TB laten : a guide for primary health care providers (Serial Online) 2019 (Cited 2019 August

1) Available from:https://www.cdc.gov/tb/publications/l tbi/treatment.htm\#two.

World Health Organisation (WHO), Global Tuberculosis Report 2014 (Serial Online) 2014 (Cited 2019 August 1). Available from:

https://www.who.int/tb/publications/global report/gtbr14 main text.pdf.

Simon AK, Hollander GA. McMichael A, 2015. Evolution of the immune system in humans from infancy to old age. Proc R Soc B, 282(1821), p.20143085.

Deng Y, Liu Y, Li Y, Jing H, Wang Y, Li X, Xu $\mathrm{L}, 2019$. Isolation measures and protection awareness are significant for TB laten : a cross-sectional study on T-SPOT.TB among health care workers in China. Epidemiology of

Doi.org/10.107/s0950268818002777.

Erawati M, Andriany M, 2020. The prevalence and demographic risk factors for latent tuberculosis infection (LTBI) among healthcare workers in Semarang, Indonesia. Journal of Multidisciplinary Healthcare, 13 197-206.

Pratomo IP, Burhan E, Tambunan V, 2012. Malnutrisi dan tuberkulosis. J Indon Med Assoc, 62(230), 7-12.

Zhang H, Li X, Xin H, Li H, Li M, Lu W, Bai L, Wang X, Liu J, Jin Q, Gao L, 2017. Association of body mass index with the tuberculosis infection: a population-based study among 17796 adults in rural China. Scientific reports, doi: 10.1038/srep41933.

Cegielski JP, McMurray DN, 2004. The relationship between malnutrition and tuberculosis: evidence from studies in humans and experimental animals. The International Journal of Tuberculosis and Lung Disease, 8(3):286-98.

Chen C, Zhu T, Wang Z, Peng H, Kong W, Zhou Y, Shao Y, Zhu L, Lu W, 2015. High latent TB infection rate and associated risk factor in the Eastern China of low TB incidence. PLoS ONE, 10 (10): e0141511.

Feng Y, Kong Y, Barnes PF, Huang F-F, Klucar $P$, Wang $X$, Samten $B$, Sengupta $M$, Machona B, Donis R, Tvinnereim A R, Shams H, 2011. Exposure to cigarette smoke inhibits the pulmonary T-Cell response to influenza virus and mycobacterium tuberculosis. Infection and Immunity, 79(1):229-37. pmid:20974820.

Robbins CS, Dawe DE, Goncharova SI, Pouladi MA, Drannik AG, Swirski FK, Cox G, 
Stampfli MR, 2004. Cigarette smoke decreases pulmonary dendritic cells and impacts antiviral immune responsiveness. Am J Respir Cell Mol Biol, doi:10.1165/rcmb.2003-02590C.

Migliori GB, Nardell E, Yedilbayev A, D'Ambrosio L, Centis R, Tadolini M, Boom MVD, Ehsani S, Sotgiu G, Dara M, 2019. Reducing tuberculosis transmission: a consensus document from the world health organization regional office for Europe. European Respiratory Journal, doi: 10.1183/13993003.00391.

Allyn PR, Brewer TF. Guide to infection control in the healthcare setting (Serial Online) 2018 (Cited 2020 September 9). Available from: International Society for Infectious Disease:https://isid.org/wpcontent/uploads/ 2019/07/ISID_GUIDE_TUBERCULOSIS. pdf

Nonghanpithak D, Reechaipichitkul W, Chaiyasung T, Faksri K, 2016. Risk factors for TB laten among health-care workers in northeastern Thailand. South East Asia Tropical Medicine and Public Health, Vol 47 No. 6.

Borroto S, Gamez D, Diaz D, Martinez Y, Ferre A I, Velasquez Y, Lianes E, Gonzales, 2011. TB laten among health care workers at a general hospital in Santiago de Cuba. Int $\mathbf{J}$ Tuberculosis Lung Disease, 15: 1510-4.

Powell K, Han D, Hung NV, Vu T, Sy DN, Trinh TT, Le TC, Do K, Oetmann JE, Whitehead S, 2011. Prevalence and risk factors for tuberculosis infection among personnel in two hospitals in Viet Nam. 9 Int $\mathbf{J}$ Tuberc Lung Dis, 15: 1643.

He GX, Wang L X, Chai S J, Klena J D, Cheng SM, Ren YL, Ren PL, Gao F, Li YY, He GM, Li JB, Rao C, Varma JK, 2012. Risk factors associated with tuberculosis infection among health care workers in Inner Mongolia, China. International Journal Tuberculosis Lung Disease, 16(11):1485-91.

Zhang X, Jia H, Liu F, Pan L, Xing A, Gu S, Du B, Sun Q, Wei R, Zhang Z, 2013. Prevalence and risk factors for latent tuberculosis infection among health care workers in China: a cross-sectional study. PLoS ONE, 8: e66412.

Park JS, 2018. The prevalence and risk factors of latent tuberculosis infection among health care workers working in a tertiary hospital in South Korea. A Journal of Clinical Medicine, 81(4):274-280.

Yoon C, Oh SY, Lee JB, Kim M, Seo Y, Yang J, Bae K, Hong S, Yang E, Kim HJ, 2017. Occupational risk of TB laten in health workers of 14 military hospital. Journal Korean Medical Science, doi.org/10.3346/jkms.2017.32.8.1251. 